\title{
Diet and reproductive aspects of the endangered butterfly ray Gymnura altavela raising the discussion of a possible nursery area in a highly impacted environment
}

\author{
Fernanda Gonçalves Silva ${ }^{1 *}{ }^{\mathbb{C}}$, Marcelo Vianna ${ }^{1}$
}

\author{
${ }^{1}$ Laboratório de Biologia e Tecnologia Pesqueira - BioTecPesca - Universidade Federal do Rio de Janeiro \\ (Av. Carlos Chagas Filho, 373 Cidade Universitária - Ilha do Fundão - Rio de Janeiro - RJ - 21941-971 - Brazil) \\ *Corresponding author: fernanda.mgs@hotmail.com
}

Identification of critical habitat is a well-recognized essential component of sustainable resource management. Nursery grounds are considered critical habitats (Medeiros et al., 2015; Rangel et al., 2018). These sites can be used by many species, separated in space and time, and it is important to understand why and how they are used, especially now, in view of the rapid decline of aquatic populations and the increase of coastal pollution (Simpfendorfer and Milward, 1993; Heithaus, 2007; Rosenfelder et al., 2012). An area used as a nursery would necessarily harbor a larger proportion of juveniles for recruitment to adult populations, on average, than would other habitats (Gunter, 1967; Beck et al., 2001). Beck et al. (2001) also emphasized the importance of these juveniles surviving and increasing in number. Generally, suitable nurseries for elasmobranchs are shallow areas with a large food supply and low predation pressure, where gravid females bear their offspring or lay their eggs and the juveniles pass their first weeks, months or years (Castro, 1993). However, the presence of an abundance of juveniles does not by itself mean that an area actually exercises this role. Heupel et al. (2007) suggested a group of criteria to identify an elasmobranch nursery area. Nursery grounds are normally located in shallow coastal areas such as estuaries (e.g. Gadig et al., 2002; Medeiros et al., 2015; Rangel et al., 2018).

These fishes have been under strong fishing pressure, and their biological vulnerability makes their management and conservation a delicate and complex matter (Dulvy et al., 2014; 2017). Authors have already cited this group of cartilaginous fish as a challenge and priority in conservation (Dulvy et al., 2017). The butterfly ray Gymnura altavela (Linnaeus, 1758) (Myliobatiformes:

Submitted on: 4/May/2018

Approved on: 8/September/2018

http://dx.doi.org/10.1590/S1679-8759201801906603
Gymnuridae) is abundant in important estuary in Rio de Janeiro, southeastern Brazil (Silva-Junior et al., 2016; Paiva et al., 2018). According to the International Union for Conservation of Nature, this specie is vulnerable worldwide, with little biological information available for the southeastern Atlantic (Vooren et al., 2007). Gymnura altavela inhabits shallow marine and brackish waters, and is widely distributed along the western and eastern Atlantic Ocean and the Mediterranean and Black seas (Weigmann, 2016). In Brazil, this ray is critically threatened, its presence is confirmed only for the southsoutheastern region, where it is under strong pressure from fishing, with a drastic decline in the catch (Vooren, 2007; ICMbio, 2014), as well as from high levels of contaminants (Rosenfelder et al., 2012).

This study aimed to analyze reproductive aspects and the nursery conditions for the butterfly ray, according to the criteria proposed by Beck et al. (2001) and Heupel et al. (2007) in eutrophic tropical estuary and also generate information about the population aspects, diet composition and reproductive biology of this endangered and littleknown specie.

Guanabara Bay $\quad\left(22^{\circ} 41^{\prime}-22^{\circ} 03^{\prime} \mathrm{S} ; \quad 043^{\circ} 16^{\prime}-\right.$ $043^{\circ} 01^{\prime} \mathrm{W}$ ) is an estuarine ecosystem, semi-enclosed, with semi-diurnal tides, tropical climate and strong marine influence. The estuary is located in South America, southeastern Brazil, in the metropolitan region of Rio de Janeiro state (Figure 1). From the bar at the bay mouth (lower estuary) to the innermost areas (upper estuary) is a natural and anthropic hydrologic gradient, which is driven both by rainfall and by the discharge of untreated domestic and industrial pollution that impact the water quality, distribution of sediments and biota (Silva-Junior et al., 2016). 


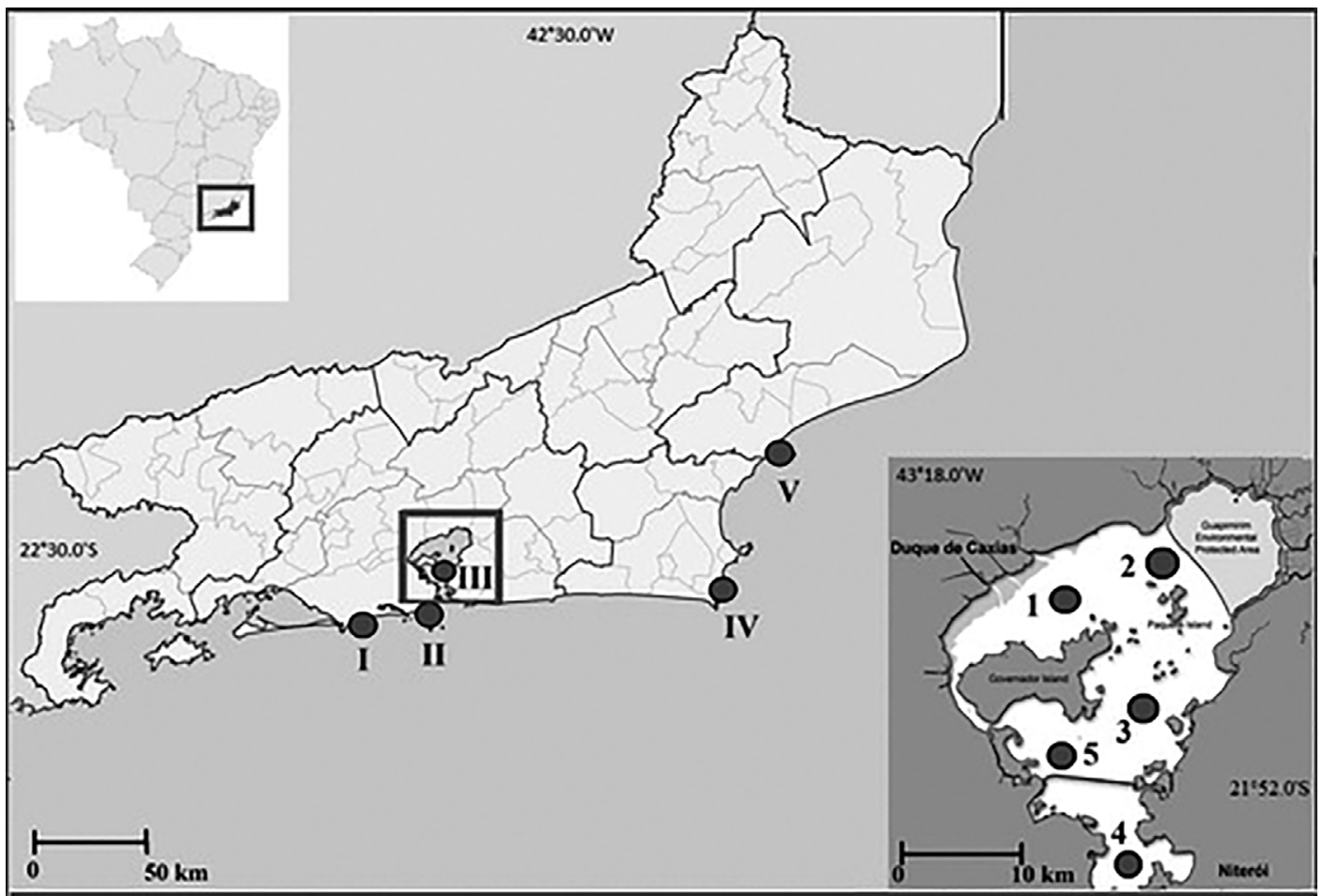

Figure 1. Map of estuary of Guanabara Bay and Rio de Janeiro state, Brazil, southwestern Atlantic, showing locations of samples taken from 2013 through 2014. I - Recreio dos Bandeirantes beach, II - Copacabana Beach, III - Guanabara Bay (taken from July 2005 through June 2007 and from November 2012 through March 2015, 1 - Duque de Caxias, 2 - Paquetá Island, 3 - Central Channel, 4 - Botafogo/Jurujuba, 5 - Governador Island and 6 - Copacabana Beach), IV - Cabo Frio city and V - Macaé city (Abreu, 2006, modified).

The biological sampling was conducted by means of scientific collections (IBAMA/Brazilian Institute of Environment and Water Resources - Permit No. 055, $12 / 05 / 2005)$ in Guanabara Bay, in two phases, targeting demersal fish. The first (Phase I) consisted of biweekly collections from July 2005 through June 2007, in five areas, with two tows per area, along the entire estuarine gradient. Areas 1 and 2 were in the upper estuary, Area 5 in the middle, and Areas 3 and 4 in the lower estuary. The second (Phase II) consisted of samples taken monthly from November 2012 through March 2015 in only Areas 3 and 5, with three tows per area (Figure 1). Samples were collected using the same trawl net and the same fishing vessel in all collections, operating at an average trawling speed of $1.5 \mathrm{knots}$. The net employed was $7 \mathrm{~m}$ long with a 14-m groundrope, and the mesh size was $18 \mathrm{~mm}$. Gymnura altavela caught were killed by cooling and then transported on ice to the laboratory, where they were frozen. The specimens was measured (disc width $\left.W_{\mathrm{D}}\right)$ in centimeters $(\mathrm{cm})$ and the total mass in grams (g) was obtained. The sex and stage of maturity (juveniles or adults) were obtained externally, by the shape and rigidity of the clasper. Females were classified by the condition of the gonads, after dissection using a ventral incision (Capapé et al., 1979).

The density and biomass of G. altavela per area trawled $\left(A_{\mathrm{T}}\right)$ were calculated using the equation: $A_{\mathrm{T}}$ $=D * h * X_{2}$, where $D$ is the distance traveled by the net in kilometers $(\mathrm{km}), h$ is the length of the headrope $(\mathrm{km})$ and $X_{2}$ is a constant that represents the fraction of the length of the headrope, referring to the width of the trajectory swept by the net mouth (Sparre and Venema, 1997). The distance traveled $(D)$ corresponds to the velocity of the tow $\left(1.5 \mathrm{knots}=2.78 \mathrm{~km} / \mathrm{h}^{-1}\right)$ multiplied by the length of time taken by the trawl $(0.5 \mathrm{~h})$. The headrope measured $0.015 \mathrm{~km}$ and the value of the constant $X_{2}$ was 0.5 (Barletta et al., 2005). The catch per unit area trawled was used to calculate the density (ind $\mathrm{km}^{-2}$ ) and biomass $\left(\mathrm{g} \mathrm{km}^{-2}\right)$, dividing the number and biomass of the individuals caught in each trawl by the area swept $\left(A_{\mathrm{T}}\right)$ (Sparre and Venema, 1997). The individuals sampled were grouped by bimesters and collection localities, in order to identify possible temporal or spatial patterns of occurrence. The numerical differences between juveniles and adults, 
males and females, and by size class $\left(W_{\mathrm{D}} \mathrm{cm}\right)$ were tested using Chi-square $\left(\chi^{2}\right)$ (Zar, 1999) Additional individuals of $G$. altavela were obtained from artisanal fishermen, at different locations on the coast of Rio de Janeiro state with different types of fishing gear and it is not possible to standardize the effort (Figure 1).

The possibility that Guanabara Bay functions as a nursery ground for $G$. altavela was examined based on the criteria of Beck et al. (2001), (i) as to the presence or absence of potential predators on the juveniles, and (ii) if abundant food is available, favoring growth. We also considered the criteria proposed by Heupel et al. (2007), including (iii) density, that is, if juvenile individuals were found in higher numbers in this area than in nearby areas; and (iv) fidelity, if the habitat is used by juveniles in successive years, while other locations are not. Only wthe requirement to determine if the same individuals tend to return frequently to the locale could not be evaluated, because another sampling method would be needed.

To determine the diet composition of $G$. altavela, the feeding biology was studied using the specimens caught in the trawls, in Guanabara Bay, these rays were caught in September 2013, February-March 2014 and August 2017. The study of stomach contents of $G$. altavela was supplemented with specimens obtained by artisanal fishing along the coast of the Rio de Janeiro state, with a gill net, between May and October 2013. The stomachs were fixed in $10 \%$ formol and after were preserved in $70 \%$ ethanol. Subsequently, were opened and their contents analyzed with the aid of a stereoscopic microscope, and the items identified to the lowest possible taxonomic level and weighed to the nearest $0.1 \mathrm{~g}$. Teleost otoliths found were measured in millimeters, and identified based on the shape and the groove of the ventral otolith, according to Corrêa and Vianna (1992-1993), and consultation in the otolith collection of the Laboratório de Mamíferos Aquáticos/ UERJ, according to Melo et al. (2010).

In the analysis of the stomach contents, the frequency of occurrence $\left(\% F_{\mathrm{O}}\right)$ and the Alimentary Index $\left(\% I_{\mathrm{AI}}\right)$ were calculated in order to evaluate the importance of each item relative to the total mass of all items (changing one of the variables to percentage mass $-\% M$ ) with the equation: $\% I_{\mathrm{AII}}=\left[\left(\% F_{\mathrm{O} 1} * \% M_{1}\right) / \Sigma\left(\% F_{\mathrm{OT}} * \% M_{\mathrm{T}}\right)\right]^{* 100}$ (see Viana et al., 2017). The otolith measurements were used in the equation $L_{\mathrm{T}}=a\left(L_{\mathrm{O}}\right)^{b}$ where $\mathrm{L}_{\mathrm{T}}$ is the total length, $a$ (23.4308) and $b(0.975)$ are constants, and $L_{\mathrm{O}}$ is the otolith length (mm), thus obtaining the size of the fish ingested (Melo et al., 2010). These data were used to determine the linear relationship $(\mathrm{y}=a \mathrm{x}+b)$ between the width of the disc of the ray and the length of the prey.

Using the larger sample number, the adjusted lengthmass relationship (LMR) was calculated by the equation $M_{\mathrm{T}=} a W_{\mathrm{D}}^{b}$, where $M_{\mathrm{T}}$ is the total mass $(\mathrm{g}), W_{\mathrm{D}}$ the disc width $(\mathrm{cm})$, and parameters $a$ and $b$ are estimated based on the least-squares method, after log-transforming the values of $M_{\mathrm{T}}$ and $W_{\mathrm{D}}$. The relationship between the disc width $\left(W_{\mathrm{D}}, \mathrm{cm}\right)$ and total length $\left(L_{\mathrm{T}} \mathrm{cm}\right)$ was obtained by $W_{\mathrm{D}}=a L_{\mathrm{T}}+b$, since the disc width as well as the total length can be used as a unit. To compare the sizes between sexes, a graph of the sex ratio with $10-\mathrm{cm}$ class intervals was constructed and the values tested for each class by $\mathrm{X}^{2}$ (Zar, 1999). The size at first sexual maturity $\left(\mathrm{L}_{50}\right)$ of the females was calculated, by the equation $p=1 / 1+\mathrm{e}^{[-r}$ (L-L50)], where $p=$ proportion of adult individuals; $r=$ rate of increase, $\mathrm{L}=$ length class and $\mathrm{L}_{50}$ the size at which $50 \%$ of individuals are mature (King, 2007). It was not possible to obtain $\mathrm{L}_{50}$ for males, due to the small number of intermediate-sized adult males, which are necessary for a good fit of the equation.

In Guanabara Bay, 64 individuals of $G$. altavela were captured, $80 \%$ juveniles, $66 \%$ males and $34 \%$ females. In the first phase, the locations with the most occurrences and higher biomassa was Duque de Caxias - upper estuary $\left(13,89\right.$ ind $\left.\mathrm{km}^{-2}, 30128 \mathrm{~g} \mathrm{~km}^{-2}\right)$, and the period of highest incidence was January-February 2007. In phase II the rays were found only at Governador Island $\left(13,76\right.$ ind $\mathrm{km}^{-2}$, $33485 \mathrm{~g} \mathrm{~km}^{-2}$ ), with the peak of occurrence in NovemberDecember 2012 (Figures 2 and 3). The proportions of both males $\left(X^{2}=9.7, \mathrm{df}=1, p<0.01\right)$ and juveniles $\left(X^{2}=35.2\right.$, $\mathrm{df}=1, p<0.01$ ) were significantly higher. The $W_{\mathrm{D}}$ ranged from $30.3-108.0 \mathrm{~cm}$ and the total individual mass from $350-11,000 \mathrm{~g}$.

Gymnura altavela was present in all the sampling years (iv) and comprised $80 \%$ of the young individuals. The analysis of feeding biology (ii) was based on 25 stomachs of specimens from Guanabara Bay, 19 of them caught with a trawl and six with a drift net. Of these, seven were empty, and were excluded from the analysis. The ray is piscivorous and feeds mainly on the whitemouth croaker, Micropogonias furnieri (Desmarest, 1823) (55.6 $F_{\mathrm{O}} \%, 51.4 I_{\mathrm{AI}} \%$ ) (Table 1). At coast of Rio de Janeiro, 47 G. altavela were use, 18 from Cabo Frio coast, 15 from Copacabana beach (adjacent to Guanabara Bay), four from Recreio dos Bandeirantes beach and one from Macaé coast. Of these, nine were empty, and were excluded from the analysis. The stomachs contained mainly teleost 

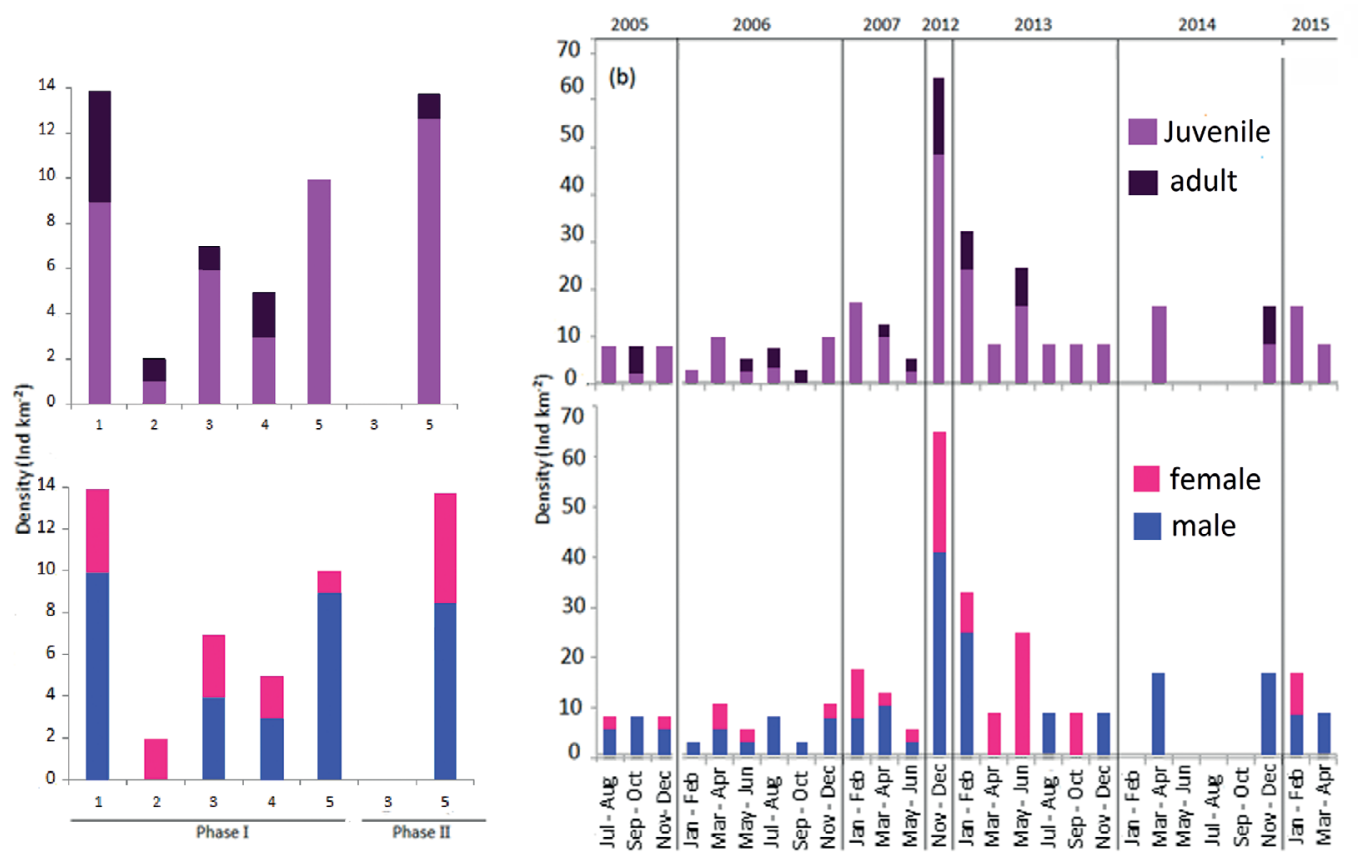

Figure 2. (a) Spatial distribution, 1- Duque de Caxias, 2- Paquetá Island, 3- Central Channel, 4- Botafogo/Jurujuba, 5- Governador Island; and (b) Temporal variation between adults and juveniles, males and females of Gymnura altavela (ind km-2) in Guanabara Bay, southwestern Atlantic (July 2005 - June 2007 and November 2012 - March 2015).
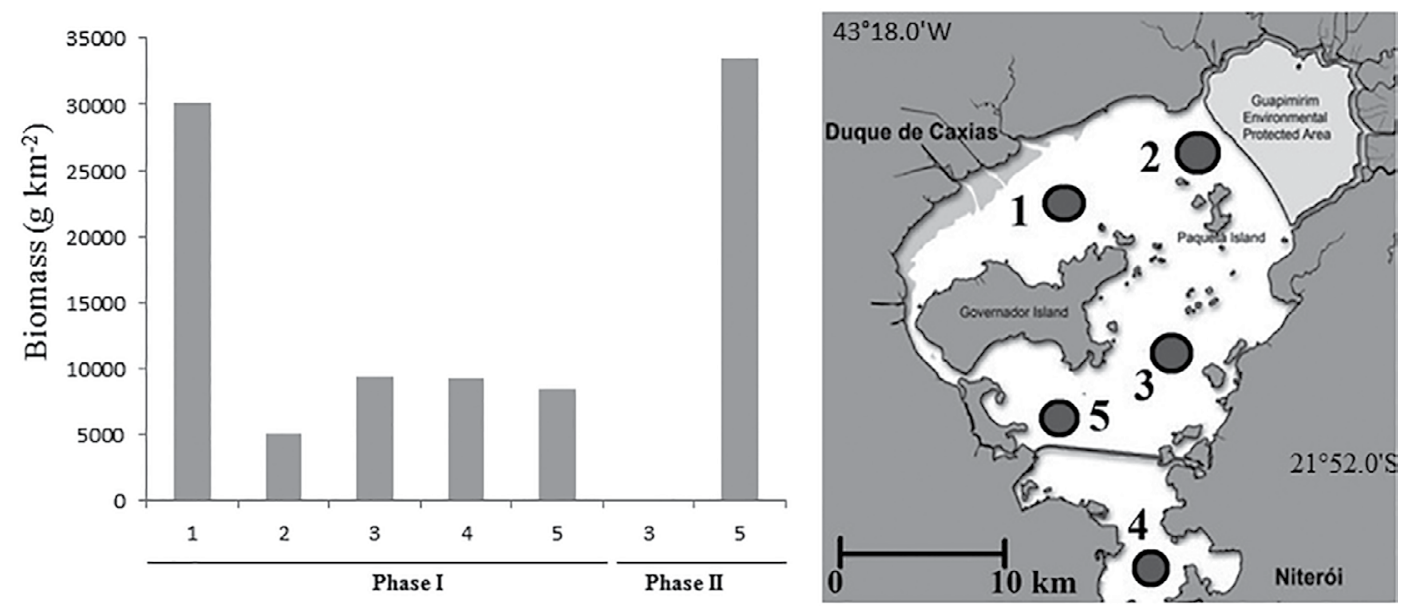

Figure 3. Spatial distribution 1- Duque de Caxias, 2- Paquetá Island, 3- Central Channel, 4- Botafogo/Jurujuba, 5- Governador Island of Gymnura altavela biomass $\left(\mathrm{g} \mathrm{km}^{-2}\right)$ in Guanabara bay, southwestern Atlantic (July 2005 - June 2007 and November 2012 - March 2015.

fragments $\left(71.0 F_{\mathrm{O}} \%, 12.0 I_{\mathrm{AI}} \%\right)$ (Table 1$)$ following for whitemouth croaker $\left(13.20 F_{\mathrm{o}} \%, 12.0 I_{\mathrm{AI}} \%\right)$. Two stomachs contained plastic material, one an entire drinking straw. A strong positive correlation $\left(\mathrm{R}^{2}=0.76\right)$ was found between the size of $G$. altavela and that of individuals of M. furnieri in the stomach contents, showing that larger rays tended to prey on larger whitemouth croakers (Figure 4).

Along the coast of Rio de Janeiro, 116 individuals of G. altavela were collected (Table 2). The relationships of length/mass and disc width/total length for males, females, and the sexes combined all showed high correlation coefficients $\left(\mathrm{r}^{2}>0.95\right)$, indicating a good fit (Table 3$)$. In most size classes, males were more abundant in the smaller classes and females in the larger classes. However, this difference was only significant in the classes of 34.0 $44.0 \mathrm{~cm}\left(\mathrm{X}^{2}=11.1 ; \mathrm{df}=1 ; p<0.01\right), 44.1-54.0 \mathrm{~cm}\left(\mathrm{X}^{2}=6.9\right.$; $\mathrm{df}=1 ; p<0.01)$ and $84.1-94.0 \mathrm{~cm}\left(\mathrm{X}^{2}=8.6 ; \mathrm{df}=1 ; p<0.05\right)$, where males were more abundant. In class $94.1-144.0 \mathrm{~cm}$, 
Table 1. Frequency of occurrence $(\% \mathrm{FO})$, percentage mass $(\% \mathrm{M})$ and alimentary index $(\% \mathrm{IAI})$ of prey items in the diet of Gymnura altavela, in Guanabara Bay and on the coast of Rio de Janeiro, Brazil, southwestern Atlantic.

\begin{tabular}{|c|c|c|c|c|c|c|}
\hline \multirow{3}{*}{ Prey Items } & \multirow{2}{*}{\multicolumn{3}{|c|}{$\begin{array}{c}\text { Guanabara Bay } \\
(n=18)\end{array}$}} & \multirow{2}{*}{\multicolumn{3}{|c|}{$\begin{array}{l}\text { Coast of Rio de Janeiro } \\
(\mathrm{n}=\mathbf{3 8})\end{array}$}} \\
\hline & & & & & & \\
\hline & $\% \mathrm{~F}_{\mathrm{o}}$ & $\% \mathbf{M}$ & $\% I_{\mathrm{AI}}$ & $\% F_{o}$ & $\% \mathbf{M}$ & $\% I_{\mathrm{AI}}$ \\
\hline \multicolumn{7}{|l|}{ Teleosts } \\
\hline Micropogonias furnieri & 55.6 & 92.5 & 51.4 & 13.2 & 55.4 & 7.1 \\
\hline Cynoscion guatupuca & - & - & - & 2.6 & 22.4 & 0.6 \\
\hline Ctenosciaena gracilicirrhus & - & - & - & 2.6 & 1.7 & 0 \\
\hline Paralonchurus brasiliensis & - & - & - & 2.6 & 2.2 & 0 \\
\hline Teleost fragments & 22.2 & 4.2 & 0.9 & 71.0 & 17.2 & 12.0 \\
\hline Sciaenidae & 5.6 & 1.8 & 0.1 & - & - & - \\
\hline Dorytheutis sp & - & - & - & 6.7 & 0 & 0 \\
\hline Itens not identified & 16.7 & 1.5 & 0.2 & 7.9 & 1.0 & 0 \\
\hline
\end{tabular}

Table 2. Total number (N), size range (WD), fishing gear, average Biomassa (AV Biomass) and total biomass (T Biomass) for Gymnura altavela on the coast of Rio de Janeiro, southwestern Atlantic.

\begin{tabular}{lccccc}
\hline Location & N & Range DW $(\mathbf{c m})$ & Gear & AV Biomass $(\mathbf{g})$ & T Biomass $(\mathbf{g})$ \\
\hline Guanabara Bay & 68 & $34.2-108.0$ & Trawl/Gill nets & 2431 & 165284 \\
Cabo Frio & 22 & $60.2-143.0$ & Gill net & 4731 & 11370 \\
Copacabana & 19 & $49.2-135.3$ & Gill net & 5903 & 112160 \\
Recreio dos Bandeirantes & 6 & $45.1-78.5$ & Gill net & 1895 & 104090 \\
Macaé & 1 & $76.1-115.8$ & Trawl & 13150 & 13150 \\
\hline
\end{tabular}

Table 3. (a) Parameters of the length-mass $\left(M_{\mathrm{T}}=a W \mathrm{D}^{\mathrm{b}}\right)$ and (b) disc width-total length $\left(W_{\mathrm{D}}=a \mathrm{LT}+\mathrm{b}\right)$ relationships for $G y m n u r a$ altavela on the coast of Rio de Janeiro, southwestern Atlantic.

\begin{tabular}{cccccccc}
\hline (a) & Sex & $\mathbf{N}$ & $\boldsymbol{W}_{\mathbf{D}}(\mathbf{c m})$ & $\boldsymbol{M}_{\mathbf{T}}(\mathbf{g})$ & $\boldsymbol{a}$ & $\boldsymbol{b}$ & $\mathbf{r}^{\mathbf{2}}$ \\
\hline & Both & 116 & $34.2-143.0$ & $329.7-25630.0$ & 0.0064 & 3.0651 & 0.9837 \\
& Female & 52 & $39.1-143.0$ & $509.3-25630.0$ & 0.0068 & 3.0498 & 0.9890 \\
& Male & 64 & $34.2-108.0$ & $329.7-11000.0$ & 0.0059 & 3.0866 & 0.9782 \\
\hline (b) & Sex & $\mathbf{N}$ & $\boldsymbol{W}_{\mathbf{D}}(\mathbf{c m})$ & $\boldsymbol{L}_{\mathbf{T}}(\mathbf{c m})$ & $\boldsymbol{a}$ & $\boldsymbol{b}$ & $\mathbf{r}^{\mathbf{2}}$ \\
\hline & Both & 101 & $35.5-143.0$ & $23.1-90.0$ & 1.4788 & 2.1398 & 0.9640 \\
& Female & 47 & $39.1-143.0$ & $26.5-90.0$ & 1.5170 & 1.5642 & 0.9772 \\
& Male & 54 & $35.5-96.8$ & $23.1-68.8$ & 1.4041 & 4.3517 & 0.9515 \\
\hline
\end{tabular}

only 11 individuals occurred, eight of which were females. The largest male caught had $W_{\mathrm{D}}$ of $108.0 \mathrm{~cm}$, and the largest female measured $143.0 \mathrm{~cm}$, showing that females reach larger sizes than males. To estimate the size at first stage of maturation $\left(\mathrm{L}_{50}\right)$ the range of $W_{\mathrm{D}}$ of the females $(\mathrm{N}=59)$ analyzed was $39.1-143.0 \mathrm{~cm}$ and the $\mathrm{L}_{50}$ was $71.7 \mathrm{~cm}$ (Figure 5).

Gymnura altavela inhabits a highly eutrophic estuary off the coast of Rio de Janeiro, southeastern Brazil and their low numbers of captured individuals reflects their critically threatened status on the coast of Brazil (ICMbio, 2014). The butterfly ray population was present mainly in the inner areas, which are more sheltered, have calmer waters, and abundant whitemouth croakers (Mulato et al., 2015), this ray's preferred food. Juveniles predominated in the population (phase I, 79\%; phase II, 81\%) and these appear to prefer the inner areas; individuals in this stage of the life cycle seek shallow, sheltered locations that can provide more food (Mulato et al., 2015) and protection (Castro, 1993; Simpfendorfer and Milward, 1993). Juveniles of G. altavela were previously reported to enter lagoons and estuaries to find sufficient resources and to develop (e.g El Kamel et al., 2009). The catch was higher in the rainy months and during the incursion of the 


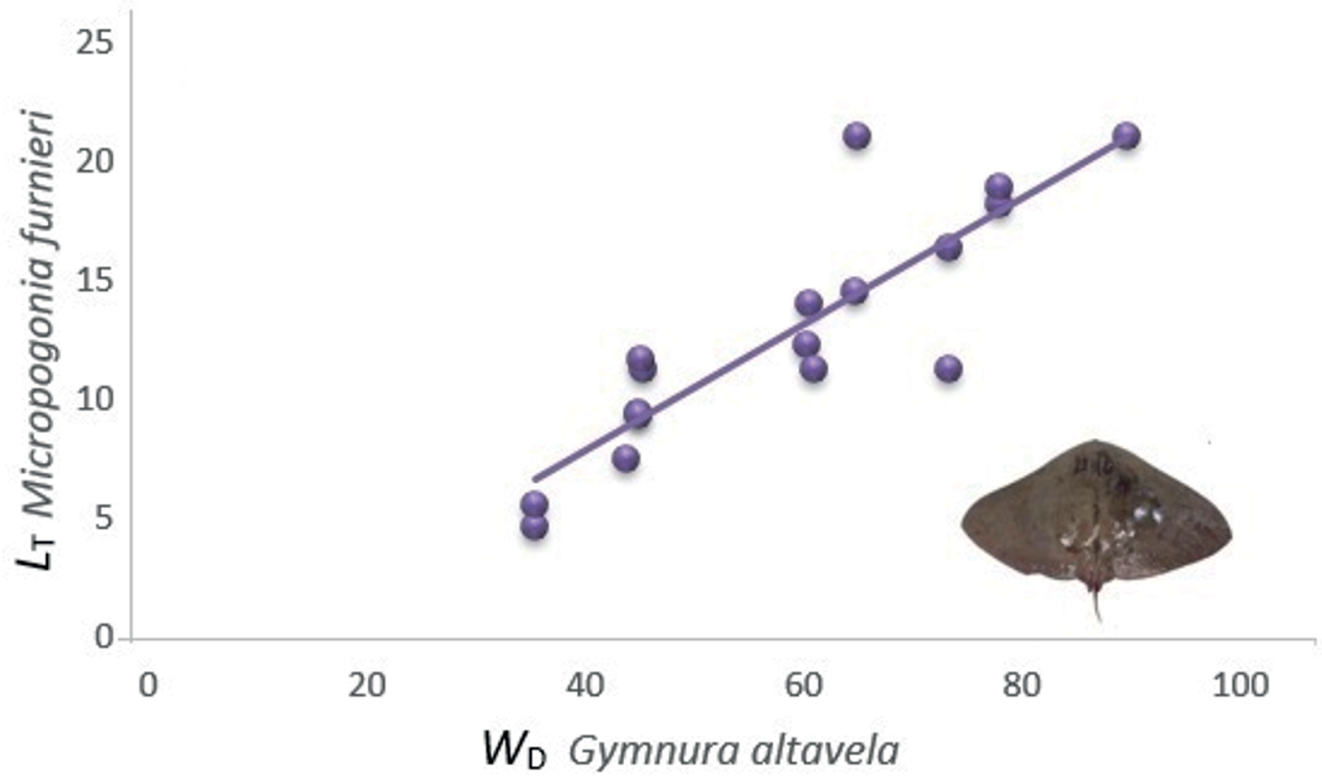

Figure 4. Correlation of Gymnura altavela disc width (WD, $\mathrm{cm}$ ) and Micropogonias furnieri total length (LT, $\mathrm{cm})$ from stomachs of G. altavela from Guanabara Bay and Copacabana Beach, southwestern Atlantic. LT $=0.2667 \mathrm{WD}-2.8586 \mathrm{R}^{2}=0.7588$.

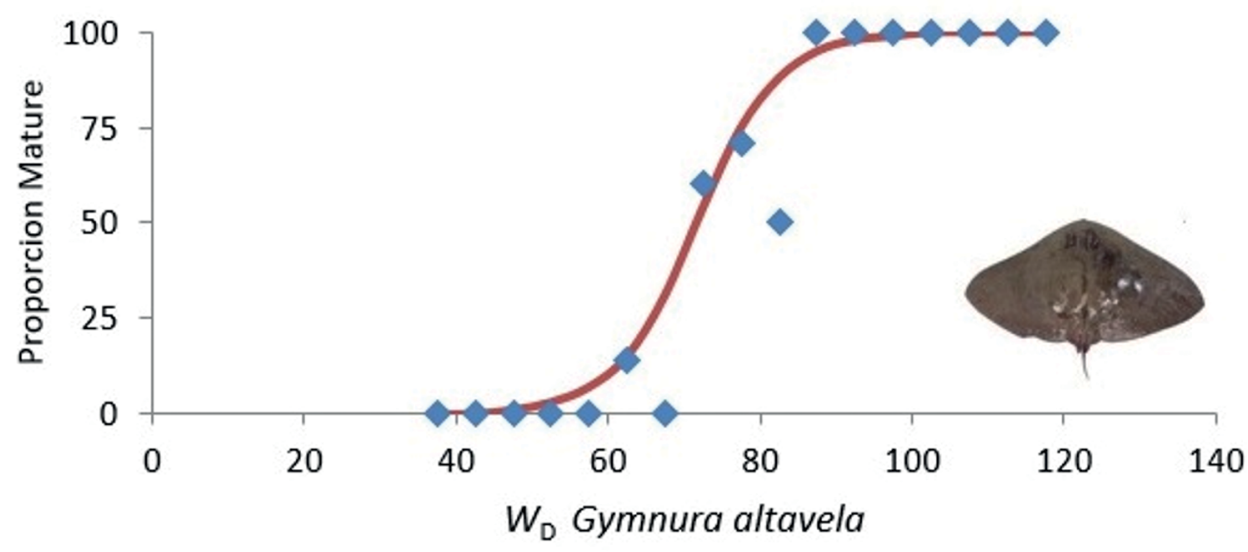

Figure 5. Graph of estimated size at first stage of maturation (L50) of females of Gymnura altavela $(\mathrm{N}=59)$. The range of disc width (WD) analyzed was 39.1-143.0 cm, on the coast of Rio de Janeiro state, southwestern Atlantic.

SACW, the period when the water column is stratified (Valentin, 1994). However, although the butterfly ray is abundant in the bay, it is rare in nearby locations. At Itaipú just east of the bay mouth, Tubino et al. (2007) found only six individuals in two years of study. At Recreio dos Bandeirantes on the coast west of the bay, Silva-Junior et al. (2008) recorded only 19 individuals also in two years.
Bays are naturally favorable nursery environments, since they are more protected and shallow, with less competition, and access of larger organisms is restricted (Rountree and Able, 1996; Ebert, 2002; Heupel and Simpfendorfer, 2011). The $80 \%$ proportion of G. altavela juveniles in the bay calls attention to the nursery potential of this locale. Nursery grounds characteristically have a 
high density of juveniles (Beck et al., 2001); however, according to Heupel et al. (2007) this alone is insufficient to define a nursery ground, which should also have more juveniles than in other, nearby locales. The samples from Copacabana, Recreio dos Bandeirantes and Cabo Frio contained similar numbers of adults and juveniles. In one study conducted in a nearby part of the coast, only $26 \%$ of the individuals caught were juveniles (Silva-Junior et al., 2008). The small number of available studies impedes the analysis of this criterion; however, the present data and the small numbers of $G$. altavela found in other parts of the coast of the state of Rio de Janeiro make it clear that Guanabara Bay has a higher density of young individuals, conforming to the criterion of Heupel et al. (2007). The species was caught in every year of sampling, and juveniles failed to be recorded in only four bimesters, showing that $G$. altavela uses this area continuously, agreeing with another criterion of Heupel et al. (2007). The last requirement could not be analyzed; individuals were not marked and recaptured, and therefore we could not determine if the juveniles leave this estuary and then return. However, in tropical waters, individuals characteristically continue to reside on the nursery ground for several years, exploiting this protected and productive area (Castro, 1993; Ebert, 2002; Heupel et al., 2007). Great sharks i.e. Galeocerdo cuvier, Carcharhinus plumbeus or Sphyrna lewini are potential predators of G. altavela (Myers et al., 2007) and none of these large predators are found in the Guanabara Bay estuary (Silva-Junior et al., 2016). Showing that butterfly ray don't have any potential predator in this area.

The feeding study showed that $G$. altavela is piscivorous, confirming that the estuary offers an abundant food supply for this ray. The main food of G. altavela was the croaker, probably because it is one of the most abundant species in Guanabara Bay (e.g. Mulato et al., 2015; SilvaJunior et al., 2016). Teleosts were important in the diets of other members of Gymnura. i.e. G. altavela in the North Atlantic (Daiber and Booth, 1960) and Mediterranean Sea (Barría et al., 2015; Yemışken et al., 2017), G. micrura in northeastern Brazil (Yokota et al., 2013), and G. australis in the South Pacific (Jacobsen et al., 2009).

The present study showed that Guanabara Bay functions as a fundamental component of the conservation of rays in the southwestern Atlantic, since it is a potential nursery area for $G$. altavela, satisfying nearly the criteria proposed by Beck et al. (2001) and Heupel et al. (2007). The coast of Syria was also considered a potential nursery ground for this species, but this supposition was based on the large number of females relative to adult males and on the abundance of gravid females (Capapé et al., 1992; Alkusairy et al., 2014). Gymnura altavela in Guanabara Bay showed a different pattern, with a larger number of males, many juveniles, and no gravid females. At Copacabana, adjacent to the bay, most rays were adult females. We believe that these females bear their young on the coast and the juveniles enter the estuary to grow. In Brazil, few publications have treated the nursery grounds of elasmobranchs in estuaries (Gadig et al., 2002; Yokota and Lessa, 2006; Andrade et al., 2008; Bornatowski, 2008; Medeiros et al., 2015; Rangel et al., 2018). However, in other parts of the world, several studies, have demonstrated the importance of estuaries for this group (e.g. Rountree and Able, 1996; Heupel and Simpfendorfer, 2008; Froeschke et al., 2010; Heupel et al., 2010; Heupel and Simpfendorfer, 2011; Norton et al., 2012; Poulakis et al., 2013; Hoff, 2016).

Gymnura altavela, although critically threatened on the coast of Brazil (ICMbio, 2014), probably at risk worldwide, and vulnerable according to the International Union for Conservation of Nature, has been little studied (Vooren et al., 2007). Data for age, size, growth and reproduction are available only for the Atlantic Ocean (Daiber and Booth, 1960; Wigley et al., 2003); Mediterranean Sea (Capapé et al., 1992; Yeldan and Avsar, 2007; Psomadakis et al., 2008; El Kamel et al., 2009; Başusta et al., 2012; Alkusairy et al., 2014; Özbek et al., 2016), Adriatic Sea (Dulčić et al., 2003) and Aegean Sea (Filiz and Bilge, 2004). A latitudinal difference can affect the size, longevity, fecundity and maturation, as observed in studies with other elasmobranchs (e.g. Horie and Tanaka, 2002; Lombardi-Carlson et al., 2003). A larger size at sexual maturity in females than in males has also been found in other studies on G. altavela (Daiber and Booth, 1960; Capapé et al., 1992; Alkusairy et al., 2014). In the present study, we found the smallest maximum disc width in both sexes, compared to reports from the Mediterranean Sea and the North Atlantic (Daiber and Booth, 1960; Alkusairy et al., 2014; Özbek et al., 2016). This small size may be caused by latitudinal differences, or may reflect a population in decline, as seen for females measuring more than $200 \mathrm{~cm}$, which were recorded in past decades (e.g. Daiber and Booth, 1960; Wigley et al., 2003) and are very probably now nonexistent. This interpretation is supported by recent results for the Syrian coast, where Alkusairy et al. (2014) found the smallest maximum sizes 
of individuals ever recorded in the Mediterranean Sea. For the size at first maturation of females, Capapé et al. (1992) obtained an $\mathrm{L}_{50}$ of $68 \mathrm{~cm}$, slightly smaller than in this study.

The butterfly ray is endangered and effective management and conservation are needed. Identification of nurseries is an essential part of a recovery plan because they facilitate recruitment to the adult population. Norton (2012) based on the criteria of Heupel (2007), designated two estuaries in the United States as Critical Habitat for the endangered sawfish Pristis pectinata. Guanabara Bay can be considered a critical habitat for G. altavela, but problems such as the pollution of this bay must be rapidly reversed, particularly because the rays ingest plastic residues, as is not unknown for the group (Joyce et al., 2002), and they show high levels of contamination (Rosenfelder et al., 2012).

\section{ACKNOWLEDGEMENTS}

I am grateful to my colleagues at BioTecPesca for collecting, measuring and dissecting the rays. This study is part of the program "Environmental Assesment of Guanabara Bay" coordinated and funded by CENPES/PETROBRAS, and the Long-Term Ecological Program (PELD), supported by CNPq (403809/2012-6) and FAPERJ (E-26/110.114/2013). Janet W. Reid (JWR Associates) revised the English text.

\section{REFERENCES}

ALKUSAIRY, H., ALI, M., SAAD A., REYNAUD, C. \& CAPAPÉ, C. 2014. Maturity, reproductive cycle, and fecundity of spiny butterfly ray, Gymnura altavela (Elasmobranchii: Rajiformes: Gymnuridae), from the coast of Syria (eastern Mediterranean). Acta Ichthyologica Et Piscatoria, 44, 229-240.

ANDRADE, A. C., SILVA-JUNIOR, L. C. \& VIANNA, M. 2008. Reproductive biology and population variables of the Brazilian sharpnose shark Rhizoprionodon lalandii (Müller \& Henle, 1839) captured in coastal waters of south-eastern Brazil. Journal of Fish Biology, 72, 473-484.

BARLETTA, M., BARLETTA-BERGAN, A., SAINT-PAUL, U. \& HUBOLD G. 2005. The role of salinity in structuring the fish assemblages in a tropical estuary. Journal of Fish Biology, 66, 45-72.

BARRÍA, C., COLL, M. \& NAVARRO, J. 2015. Unravelling the ecological role and trophic relationships of uncommon and threatened elasmobranchs in the western Mediterranean Sea. Marine Ecology Progress Series, 539, 225-240.

BAŞUSTA, N. \& ERDEM, Ü. 2000. A study on the pelagic and demersal fishes of Iskenderun Bay Turkish. Turkish Journal of Zoology, 24, 1-19.

BECK, M. W., HECK, JR, K. L., ABLE, K. W., CHILDERS, D. L., EGGLESTON, D. B., GILLANDERS, B. M., HALPERN, B., HAYS, C. G., HOSHINO, K., MINELLO, T. J., ORTH, R. J., SHERIDAN, P. F. \& WEINSTEIN M. P. 2001. The Identification, Conservation, and Managemente of Estuarine and Marine Nurseries for Fish and Invertebrates. BioScience, 51, 633-641.
BORNATOWSKI, H. 2008. A parturition and nursery area for Carcharhinus limbatus (Elasmobranchii, Carcharhinidae) off the coast of Paraná, Brazil. Brazilian Journal of Oceanography, 56, 317-319.

CAPAPÉ, C. 1979. La torpille marbrée, Torpedo marmorata Risso, 1801 (Pisces, Rajiformes) des côtes tunisiennes: nouvelles données sur l'écologie et la biologie de la reproduction de l'espèce avec une comparaison entre les populations méditerranéennes et atlantiques. Annales des Sciences Naturelle Paris, 1, 79-97.

CAPAPÉ, C., ZAOUALI, J., TOMASINI, J. A. \& BOUCHEREAU, J. L. 1992. Reproductive biology of the spiny butterfly ray, Gymnura altavela (Linnaeus, 1758) (Pisces: Gymnuridae) from off the Tunisian coasts. Scientia Marina, 56, 347-355.

CASTRO, J. I. 1993. The shark nursery of Bulls Bay, South Carolina, with a review of the shark nurseries of the southeastern coast of the United States. Environmental Biology of Fishes, $38,37-48$

CORRÊA, M. F. M. \& VIANNA, M. S. 1992/1993. Catálogo de otólitos de Sciaenidae (Osteichthyes - Perciformes) do litoral do estado do Paraná, Brasil. Nerítica, 7, 13-41.

DAIBER, F. C. \& BOOTH, R. A. 1960. Notes on the biology of the butterfly rays, Gymnura altavela and Gymnura micrura. Copeia, 2, 137-139.

DULČIĆ, J., JARDAS, I., ONOFRI, V. \& BOLOTIN, J. 2003. The roughtail stingray Dasyatis centroura (Pisces: Dasyatidae) and spiny butterfly ray Gymnura altavela (Pisces: Gymnuridae) from the southern Adriatic. Journal of the Marine Biological Association of the United Kingdom, 83, 871-872.

DULVY, N. K., FOWLER, S. L., MUSICK J. A., CAVANAGH, R. D., KYNE, P. M., HARRISON, L. R., CARLSON, J. K., DAVIDSON, N. K., FORDHAM, S. V., FRANCIS, M. P., POLLOCK, C. M., SIMPFENDORFER, C. A., BURGESS, G. H., CARPENTER, K. E., COMPAGNO, L. J. V., EBERT, D. A., GIBSON, C., HEUPEL, M. R., LIVINGSTONE, S. R., SANCIANGO, J. C., STEVENS, J. D., VALENTI, S. \& WHITE, W. T. 2014. Extinction risk and conservation of the world's sharks and rays. eLife, 3 , e00590.

DULVY, N. K., SIMPFENDORFER, C. A., DAVIDSON, L. N. K., FORDHAM, S. V., BRÄUTIGAM, A., SANT, G. \& WELCH, D. J. 2017. Challenges and Priorities in Shark and Ray Conservation. Current Biology, 27, R565-R572.

EBERT, D. A. 2002. Ontogenetic changes in the diet of the sevengill shark (Notorynchus cepedianus). Marine and Freshwater Research, 53, 517-523.

EL KAMEL, O., MNASRI, N., SOUISSI, J. B., BOUMAÏZA, M., AMOR, M. M. B. \& CAPAPÉ, C. 2009. Inventory of elasmobranch species caught in the Lagoon of Bizerte (North-eastern Tunisia, central Mediterranean). Pan-American Journal of Aquatic Sciences, 4, 383-412.

FILIZ, H. \& BILGE, G. 2004. Length-weight relationships of 24 fish species from the North Aegean Sea, Turkey. Journal of Applied Ichthyology, 20, 431-432.

FROESCHKE, J. T., STUNZ, G. W., STERBA-BOATWRIGHT, B. \& WILDHABER, M. L. 2010. An empirical test of the 'shark nursery area concept' in Texas bays using long-term fisheries-independent data set. Aquatic Biology, 11, 65-76.

GADIG, O. B. F., MOTTA, F. S. \& NAMORA, R. C. 2002. Projeto Cação: a study on small coastal sharks in São Paulo, southeast Brazil. In: DUARTE, P. (ed.) Proceedings of the International Conference on Sustainable Management of Coastal Ecosystems. Porto: Universidade Fernando Pessoa, 239-246. 
GUNTER, G. 1967. Some relationships of estuaries to the fisheries of the Gulf of Mexico. In: LAUFF, G. H. (eds.) Estuaries, vol. 83. Washington: American Association for the Advancement of Science Publication.

HEITHAUS, M. R. 2007. Nursery Areas as Essential Shark Habitats: A Theoretical Perpesctive. American Fisheries Society Symposium, 50, 3-13.

HEUPEL, M. R., CARLSON, J. K. \& SIMPFENDORFER, C. A. 2007. Shark nursery areas: concepts, definition, characterization and assumptions. Marine Ecology Progress Series, 337, 287-297.

HEUPEL, M. R., YEISER, B. G., COLLINS, A. B., ORTEGA, L. \& SIMPFENDORFER, C. A. 2010. Long-term presence and movement patterns of juvenile bull sharks, Carcharhinus leucas, in an estuarine river system. Marine and Freshwater Research, 61, 1-10.

HEUPEL, M. R. \& SIMPFENDORFER, C. A. 2011. Estuarine nursery areas provide a low-mortality environmental for young bull sharks Carcharhinus leucas. Marine Ecology Progress Series, 433, 237-244.

HOFF, G. R. 2016. Identification of multiple nursery habitats of skates in the eastern Bering Sea. Journal of Fish Biology, 88, 1746-1757.

HORIE, T. \& TANAKA, S. 2002. Geographical variation of maturity size of the cloudy catshark, Scyliorhinus torazame, in Japan. Journal of the Faculty of Marine Science and Technology Tokai University, 53, 111-124.

ICMBIO, 2014. (Instituto Chico Mendes de Conservação da Biodiversidade). Lista das Espécies da Fauna Brasileira Ameaçadas de Extinção [cited 2018 Jan 8]. Available from: http://www. icmbio.gov.br/portal/faunabrasileira/lista-de-especies

JACOBSEN, I. P., JOHNSON, J. W. \& BENNETT, M. B. 2009. Diet and reproduction in the Australian butterfly ray Gymnura australis from northern and north-eastern Australia. Journal of Fish Biology, 75, 2475-2489.

JOYCE, W. N, CAMPANA, S. E., NATANSON, L. J., KOHLER, N. E., PRATT, JR, H. L. \& JENSEN, C. F. 2002. Analysis of stomach contents of the porbeagle shark (Lamn nasus Bonnaterre) in the northwest Atlantic. ICES Journal of Marine Science, 59, 1263-1269.

KING, M. 2007. Fisheries Biology, Assessment and Management. $2^{\text {nd }}$ Ed. Oxford, UK: Blackwell Publishing.

LOMBARDI-CARLSON, L. A., CÓRTES, E., PARSONS, G. R. \& MANIRE, C. A. 2003. Latitudinal variation in life-history traits of bonnethead sharks, Sphyrna tiburo, (Carcharhiniformes: Sphyrnidae) from the eastern Gulf of Mexico. Marine and Freshwater Research, 54, 875-883.

MEDEIROS, A. M., LUIZ, O. J. \& DOMIT, C. 2015. Occurrence and use of an estuarine habitat by giant manta ray Manta birostris. Journal of Fish Biology, 86, 1830-1838.

MELO, C. L. C., SANTOS, R. A., BASSOI, M., ARAÚJO, A. C., LAILSON-BRITO, J., DORNELES P. R. \& AZEVEDO, A. F. 2010. Feeding habits of delphinids (Mammalia: Cetacea) from Rio de Janeiro State, Brazil. Journal of the Marine Biological Association of the United Kingdom, 90, 1509-1515.

MULATO I. P., CORRÊA B. \& VIANNA M. 2015. Distribuição Espaço-Temporal de Micropogonias furnieri (Perciformes, Sciaenidae) em um estuário Tropical no Sudeste do Brasil. Boletim do Instituto de Pesca (São Paulo), 41, 1-18.
MYERS, R. A., BAUM, J. K., SHEPHERD, T. D., POWERS, S. P. \& PETERSON, C. H. 2007. Cascading Effects of the Loss of Apex Predatory Sharks from a Coastal Ocean. Science, 315, 1846-1850.

NORTON, S. L., WILEY, T. R., CARLSON, J. K., FRICK, A. L., POULAKIS, G. R. \& SIMPFENDORFER, C. A. 2012. Designating critical habitat for juvenile endangered smalltooth sawfish in the United States. Marine and Coastal Fisheries. Dynamics, Management, and Ecosystem Science, 4, 473-480.

ÖZBEK, E. Ö., ÇARDAK, M. \& KEBAPÇIOĞLU, T. 2016. Spatio-temporal patterns of abundance, biomass and length-weight relationships of Gymnura altavela (Linnaeus, 1758) (Pisces: Gymnuridae) in the Gulf of Antalya, Turkey (Levantine Sea). Journal of the Black Sea/Mediterranean Environment, 22, 1634.

PAIVA, L. G., JULIO, T. G., MARQUES, R. A. \& VIANNA, M. 2018. First description of the embryos of the stingray Gymnura altavela (Linnaeus, 1758) (Myliobatiformes: Gymnuridae), a species at risk of extinction. Journal of Applied Ichthyology, 34, 984-987.

POULAKIS, G. R., STEVENS, P. W., TIMMERS, A. A., STAFFORD, C. J. \& SIMPFENDORFER, C. A. 2013. Movements of juvenile endangered smalltooth sawfish, Pristis pectinata, in an estuarine river system: use of non-main-stem river habitats and lagged responses to fresh water inflow-related changes. Environmental Biology of Fishes, 96, 763-778.

PSOMADAKIS, P. N., DALÙ, M., SCACCO, U. \& VACCHI, M. 2008. A rare batoid fish Gymnura altavela (Chondrichthyes: Gymnuridae) captured in the Tyrrhenian Sea. Marine Biodiversity Records, 1, 1-4.

RANGEL, B. S., RODRIGUES, A. \& MOREIRA, R. G. 2018. Use of a nursery area by cownose rays (Rhinopteridae) in southeastern Brazil. Neotropical Ichthyology, 16, e170089.

ROSENFELDER, N., LEHNERT, K., KAFFARNIK, S., TORRES, J. P. M., VIANNA, M. \& VETTER, W. 2012. Thorough analysis of polyhalogenated compounds in ray liver samples off the coast of Rio de Janeiro, Brazil. Environmental Science and Pollution Research, 19, 379-389.

ROUNTREE, R. A. \& ABLE, K. W. 1996. Seasonal abundance, growth, and foraging habits of juvenile smooth dogfish, Mustelus canis, in a New Jersey estuary. Fisheries Bulletins, 94, 522-534.

SILVA-JUNIOR, L. C., ANDRADE, A. C. \& VIANNA, M. 2008. Caracterização de uma pescaria de pequena escala em uma área de importância ecológica para elasmobrânquios, no Recreio dos Bandeirantes, Rio de Janeiro. Arquivos de Ciências do Mar, 41, 47-57.

SILVA-JUNIOR, D. R., PARANHOS, R. \& VIANNA, M. 2016. Spatial patterns of distribution and the influence of seasonal and abiotic factors on demersal ichthyofauna in an estuarine tropical bay. Journal of Fish Biology, 89, 821-846.

SIMPFENDORFER, C. A. \& MILWARD, N. E. 1993. Utilisation of a tropical bay as a nursery area by sharks of the families Carcharhinidae and Sphyrnidae. Environmental Biology of Fishes, 37, 337-345.

SPARRE, P. \& VENEMA, S. C. 1997. Introdução à avaliação de mananciais de peixes tropicais. Parte 1: Manual. Roma: Danida/FAO, 334-342.

STONER, A. W. 2003. What constitutes essential nursery habitat for a marine species? A case study of habitat form and function for queen conch. Marine Ecology Progress Series, 257, 275-289. 
TUBINO, R. A., MONTEIRO-NETO, C., MORAES, L. E. S. \& PAES, E. T. 2007. Artisanal Fisheries Production in the Coastal Zone of Itaipu, Niterói, RJ, Brazil. Brazilian Journal of Oceanography, 55, 187-197.

VALENTIN, J. L. 1994. A ressurgência fonte de vida dos oceanos. Ciência Hoje, 18, 19-25.

VIANA, A. F., VALENTIN, J. L. \& VIANNA, M. 2017. Feeding ecology of elasmobranch species in southeastern Brazil. Neotropical Ichthyology, 15, e160176.

VOOREN, C. M., PIERCY, A. N., SNELSON, JR., F. F., GRUBBS, R. D., NOTARBARTOLO DI SCIARA, G. \& SERENA, S. 2007. Gymnura altavela. In: The IUCN Red List of Threatened Species. Version 2014.3 [cited 2018 Jan 8]. Available from: www.iucnredlist.org

WEIGMANN, S. 2016. Annotaded checklist of the living sharks, batoids and chimaeras (Chondrichthyes) of the world, with a focus on biogeographical diversity. Journal of Fish Biology, 88, 837-1037.

WIGLEY, S. E., MCBRIDE, H. M. \& MCHUGH, N. J. 2003. Length-weight relationships for 74 fish species collected during NEFSC research vessel bottom trawl surveys, 1992-99. NOAA Technical Memorandum, nMFS-nE 171. Woods Hole, MA: U. S. Department of Commerce, National Oceanic and Atmospheric Administration, National Marine Fisheries Service, Northeast Fisheries Science Center.
YELDAN, H. \& AVSAR, D. 2007. Length-weight relationship for five elasmobranch species from the Cilician Basin shelf waters (Northeastern Mediterranean). Journal of Applied Ichthyology, 23, 713-714.

YEMIŞKEN E., FORERO, M. G., MEGALOFONOU, P., ERYILMAZ, L. \& NAVARRO, J. 2017. Feeding habits of three Batoids in the Levantine Sea (north-eastern Mediterranean Sea) based on stomach content and isotopic data. Journal of the Marine Biological Association of the United Kingdom, 98, 89-96.

YOKOTA, L. \& LESSA, R. P. 2006. A nursery area for sharks and rays in Northeastern Brazil. Environmental Biology of Fishes, 7, 349-360.

YOKOTA, L., GOITEIN, R., GIANETI, M. D. \& LESSA, R. T. P. 2013. Diet and feeding strategy of smooth butterfly ray Gymnura micrura in northeastern Brazil. Journal of Applied Ichthyology, 29, 1325-1329.

ZAR, J. H. 1999. Biostatistical Analysis, $4^{\text {th }}$ ed. Upper Saddle River, NJ, Prentice Hall. 